\title{
眼瞼黄色腫患者の臨床像とプロブコールによる 治療効果について
}

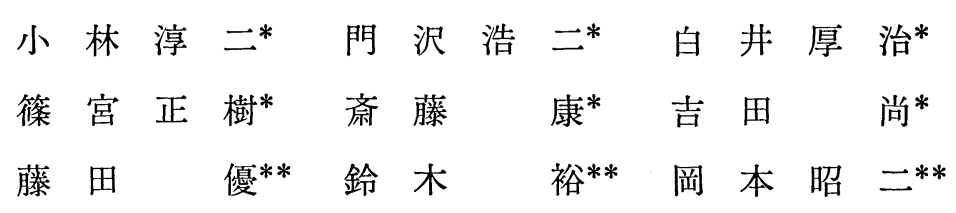

\section{I. はじめに}

眼瞼黄色腫にはアテローム硬化巣と同様にコレ ステロールエステルが蓄積している1). 本症は, 家族性高コレステロール血症 (FHC) の約 $17 \%$ に 合併するとされているが, 高脂血症を認めない症 例にも発症することもあり, 血清脂質とその成因 との関係は必ずしも明らかではない2,3). 合併症 に関しては, 眼瞼黄色腫患者では, 血清脂質が正 常でも虚血性心疾患の合併する率は高いとの報告 もみられる4).

本症は自然経過では一般に退縮しにくく, 治療 法として外科的摘出が行われることもあるが, 再 発することもあり, 現在, 満足すべき治療法は確 立されていない。

近年, 脂質低下剤として開発されたプロブコー ルを眼瞼黄色腫を有する家族性高コレステロール 血症 $(\mathrm{FHC})$ 患者に投与すると, その眼瞼黄色腫 が退縮した ${ }^{4)}$ との報告がある.

そこで今回, 眼瞼黄色腫を有した患者の臨床像 とリポ蛋白像を明らかにし, さらにプロブコール の投与を試み，眼瞼黄色腫の退縮に及ぼす効果を 検討したので報告する.

\footnotetext{
* 千葉大学医学部附属病院第二内科

** 同皮膚科

原稿受取日：1988 年 11 月 4 日

採用決定日：1989年 3 月 8 日
}

\section{II. 対象と方法}

対象は眼瞼黄色腫を有する家族性高コレステロ ール血症 (FHC) 26例 (男性16例, 女性10例, 平均 年齢 52.1 歳) と非家族性高コレステロール血症 (non FHC) 29例 (男性 6 例, 女性 23例, 平均年齢 53.3 歳)の計 55 例であった. FHC の診断は馬㴊 ら5) の基準に従った. リポ蛋白像を解析するため の対照群として眼瞼黄色腫を有さないFHC 127 例, non FHC 高コレステロール血症 18 例, およ び正常対照者 104 例を抽出した. プロブコール投 与量は原則として 1 日 $500 \mathrm{mg}$ から $1,000 \mathrm{mg}$ と し，12 か月間投与した. 血清総コレステロール (TC) 值, 中性脂肪 (TG) 值は, 酵素法で測定し, 高比重リポ蛋白コレステロール (HDL-C) 值は沈 澱法で測定した. リポ蛋白分画は LpTi ローター を用いて超遠心法6) で, アポ蛋白は免疫比濁法に て測定した. Apo E phenotype は等電点電気泳 動》にて診断した.

\section{III. 成 績}

\section{1. 眼瞼黄色腫保有患者の血清脂質值}

Figure 1 に対象症例群の TG 值を縱軸に, TC 值を横軸にプロットした結果を示す. 対象症例 群の TC 值は 175 480 mg/d $l$, TG 值は 55 220 $\mathrm{mg} / \mathrm{d} l$ まで分布し, 単独で高 TG 血症を示した症 例はみられなかった。 そこで TC 值に関して, 高 コレステロール血症群 $(\mathrm{TC} \geqq 230 \mathrm{mg} / \mathrm{d} l)$ と正コレ 
ステロール群 $(\mathrm{TC}<230 \mathrm{mg} / \mathrm{d} l)$ とに分けてみると, 前者には, 高コレステロール血症 $(\mathrm{TC} \geqq 250 \mathrm{mg} /$ $\mathrm{d} l$ ) の家族歴やアキレス腱肥厚 (アキレス腱厚 $\geqq 9$ $\mathrm{mm})$ を有する FHC 群が含まれていた7)。そこで, 対象症例を FHC 群, 非 FHC 高コレステロール 血症 (non FHC-hyper TC) 群, 正コレステロール (normo TC) 群の 3 群に分けて, その臨床像, リ ポ蛋白像および治療効果について検討を試みた.

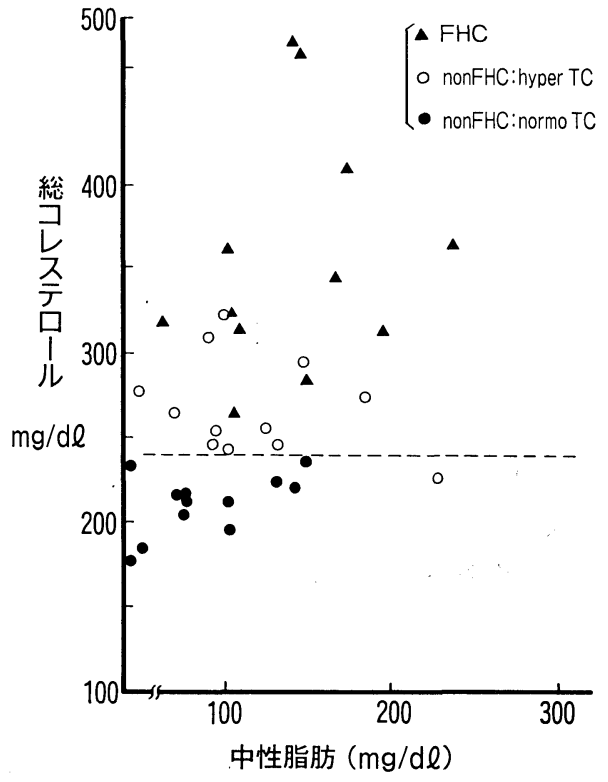

Fig. 1 Serum lipids levels in xanthelasma patients.

Table 1 Classification of xanthelasma patients and the complications

\begin{tabular}{|c|c|c|}
\hline & $\begin{array}{ll}\text { 例数(人) 年令(f) } \\
\end{array}$ & 合併症 \\
\hline $\begin{array}{l}\text { 家族性 } \\
\text { 高コレステロール } \\
\text { 血症群 } \\
\text { (FHC) }\end{array}$ & $\left.\begin{array}{ll}\text { 男 } & 16 \\
\text { 女 } & 10\end{array}\right\}_{(7)}^{26} * 52.1$ & $\begin{array}{ll}\text { DM } & 16 \% \\
\text { IHD } & 50 \%\end{array}$ \\
\hline $\begin{array}{l}\text { non-FHC } \\
\text { 高コレステロール } \\
\text { 血症群 } \\
\text { (TC } \geq 230 \mathrm{~m} / \mathrm{dl})\end{array}$ & $\left.\begin{array}{lc}\text { 男 } & 5 \\
\text { 女 } & 10\end{array}\right\} 15 \quad 56.6$ & $\begin{array}{ll}\text { Psoriasis } & 1 \\
\text { DM } & 1\end{array}$ \\
\hline $\begin{array}{l}\text { non-FHC } \\
\text { 正コレステロール } \\
\text { 群 } \\
\text { (TC<230ma/de) }\end{array}$ & $\left.\begin{array}{ll}\text { 男 } & 1 \\
\text { 女 } & 13\end{array}\right\} \begin{array}{ll}14 & 49.8\end{array}$ & $\begin{array}{lc}\text { SLE } & 1 \\
\text { SSS syndrome } 1 \\
\text { PN } 1 \\
\text { Lichen planus 1 }\end{array}$ \\
\hline
\end{tabular}

*皮䖉科初診者FHC(皮虚科の眼臉黄色腫患者の20\%)
Table 1 に示すごとく, FHC 群では, $50 \%$ の 症例に虚血性心疾患がみられ，16\%の症例が糖尿 病を合併していた。 non FHC-hyper TC 群では, 約 7\%の症例が糖尿病を合併していた. non FHC-normo TC では，動脈硬化性疾患の症状を 示した症例はなかったが，全身性エリテマトーデ ス，シェグレン症候群，結節性動脈周囲炎などの 膠原病を合併する症例が散見された．以下，これ ら各群の臨床像とリポ蛋白像を眼瞼黄色腫を有さ ない対照症例群と比較検討した。

\section{3 群それぞれの眼瞼黄色腫保有患者の血清} リポ蛋白, アポ蛋白および臨床像

\section{a) FHC 群}

Figure 2 に FHC 群の中で眼瞼黄色腫保有患者 (眼瞼黄色腫患者) と眼瞼黄色腫非保有患者 (非保 有患者)の各種リポ蛋白画分の血清脂質値とアポ 蛋白值を比較検討した成績を示す.

眼瞼黄色腫患者では, 血清 TC 值, 低比重リポ 蛋白コレステロール (LDL-C) 值, apo B 值は,

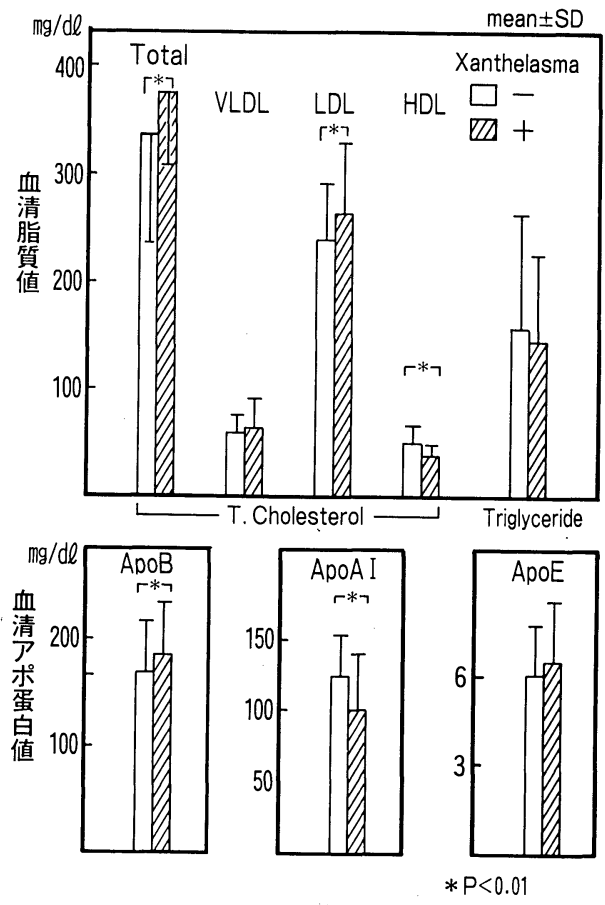

Fig. 2 Serum lipids and apolipoproteins levels in xanthelasma patients.

-Familial hypercholesterolemia (FHC)- 
Table 2 Clinical pictures of FHC subjects with xanthelasma

\begin{tabular}{|c|c|c|}
\hline & \multicolumn{2}{|c|}{ 眼 瞼 黄色腫 } \\
\hline & + & - \\
\hline $\begin{array}{l}\text { 例 数 } \\
\text { (男、女) }\end{array}$ & $\begin{array}{c}26 \\
(16,10) \\
\end{array}$ & $\begin{array}{c}127 \\
(76,51)\end{array}$ \\
\hline 年 & $52.1 \pm 8.8$ & $45.1 \pm 15.5$ \\
\hline $\begin{array}{c}\text { アキレス腱肥厚 } \\
(\mathrm{mm})\end{array}$ & $14.5 \pm 6.0$ & $11.5 \pm 4.5$ \\
\hline $\begin{array}{l}\text { 虚血性心疾患 } \\
\left(\begin{array}{l}\text { ECG異常 } \\
\text { 狭心症 } \\
\text { 心筋梗塞 } \\
\text { そ の他 }\end{array}\right.\end{array}$ & $\begin{array}{l}50 \% \\
22 \\
17 \\
6 \\
5 \\
\end{array}$ & $\begin{array}{l}37 \% \\
\left(\begin{array}{c}20 \\
9 \\
7 \\
1\end{array}\right. \\
\end{array}$ \\
\hline $\begin{array}{l}\text { 冠動脈狭窄 } \\
\text { スコア }\end{array}$ & $\begin{array}{c}11.3 \pm 3.0 \\
n=3\end{array}$ & $\begin{array}{c}9.35 \pm 8.15 \\
n=20\end{array}$ \\
\hline
\end{tabular}

それぞれ, $373 \pm 67 \mathrm{mg} / \mathrm{d} l, 263 \pm 65 \mathrm{mg} / \mathrm{d} l, 185 \pm$ $50 \mathrm{mg} / \mathrm{d} l$ と非保有患者の $336 \pm 99 \mathrm{mg} / \mathrm{d} l, 236 \pm 53$ $\mathrm{mg} / \mathrm{d} l, 168 \pm 48 \mathrm{mg} / \mathrm{d} l$ と比較して有意に高く,

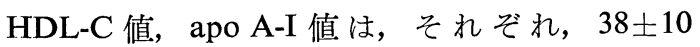
$\mathrm{mg} / \mathrm{d} l, 101 \pm 39 \mathrm{mg} / \mathrm{d} l$ と非保有患者の $52 \pm 17 \mathrm{mg} /$ $\mathrm{d} l, 123 \pm 29 \mathrm{mg} / \mathrm{d} l$ と比較して有意に低かった.

Table 2 に眼瞼黄色腫患者と 非保有患者の 臨床像 を比較した成績を示す. 眼瞼黄色腫患者では, ア キレス腱肥厚は，平均 $14.5 \pm 6.0 \mathrm{~mm}$ と非保有患 者の平均 $11.5 \pm 4.5 \mathrm{~mm}$ と比較してより高度であ った．また，虚血性心疾患の合併率もより高度で あった.さらに，冠動脈造影を施行された症例に ついて冠動脈狭窄度を反映する指標として冠動脈 狭窄スコア9)をもとめると, その平均值は眼瞼黄 色腫患者では $11.3 \pm 3.0$ と非保有患者の $9.35 \pm$ 8.15 と比較して高い傾向がみられた。

b) non FHC-hyper TC 群

Figure 3 に non FHC-hyper TC 群にて眼瞼黄 色腫患者と非保有患者のリポ蛋白画分の血清脂質 值とアポ蛋白值を比較検討した成績を示す. 両群 の血清 TC 值の match した症例を選んで比較する と, 前者では apo B 值は $142 \pm 10 \mathrm{mg} / \mathrm{d} l$ と後者 での $129 \pm 12 \mathrm{mg} / \mathrm{d} l$ と比較して有意に高く, HDLC 值, apo A-I 值でそれぞれ $46 \pm 8.1 \mathrm{mg} / \mathrm{d} l, 117$ $\pm 12.2 \mathrm{mg} / \mathrm{d} l$ と後者での $60 \pm 8.8 \mathrm{mg} / \mathrm{d} l, 149 \pm$ $13.8 \mathrm{mg} / \mathrm{d} l$ に比較して有意に低かった.

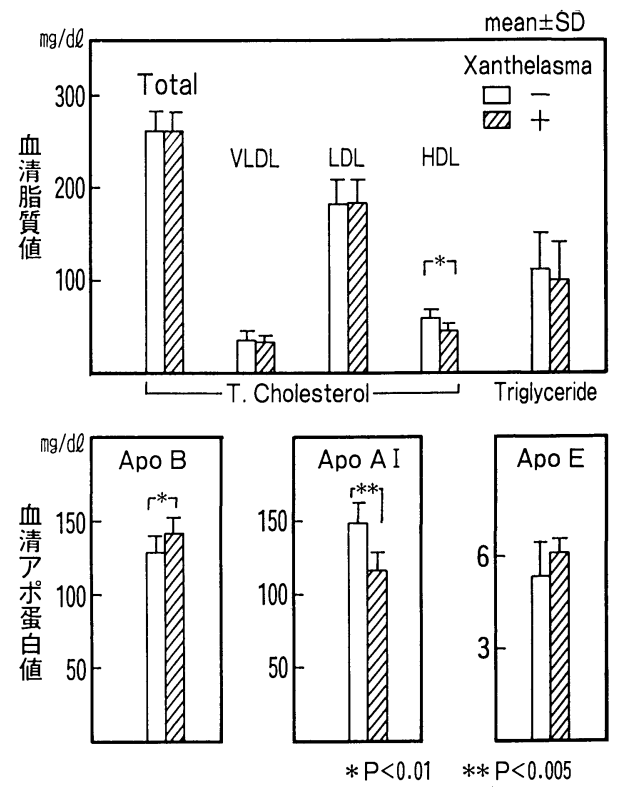

Fig. 3 Serum lipids and apolipoproteins levels in xanthelasma patients.

-Non FHC hypercholesterolemia-

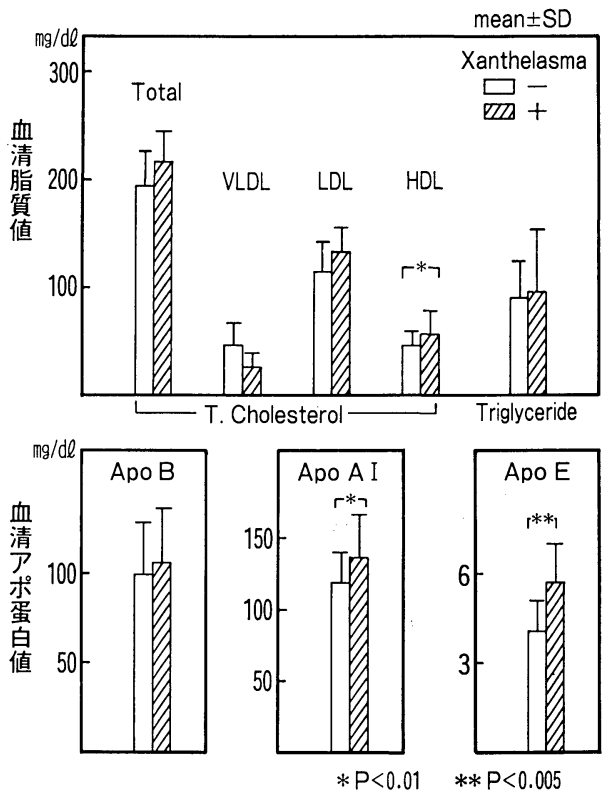

Fig. 4 Serum lipids and apolipoproteins levels in xanthelasma patients.

-Non FHC normocholesterolemia-

c) non FHC-normo TC 群

Figure 4 に non FHC-normo TC 群にて眼瞼黄 色腫患者と正常対照者のリポ蛋白画分の血清脂質 
動脈硬化 Vol. 17 No. 31989

Table 3 Frequency of several apo E phenotypes in xanthelasma patients and normal controls

\begin{tabular}{|c|c|c|c|c|c|c|}
\hline & \multicolumn{5}{|c|}{ Apo E phenotype } & \multirow{2}{*}{ Total } \\
\hline & $3 / 3$ & $3 / 2$ & $4 / 3$ & $4 / 4$ & $4 / 2$ & \\
\hline \multicolumn{7}{|l|}{ Xanthelasma patients } \\
\hline \multirow[t]{2}{*}{ FHC } & 5 & 1 & & & & $6^{*}$ \\
\hline & (83) & (17) & & & & $(100)^{* *}$ \\
\hline \multirow[t]{2}{*}{ non FHC-hyper TC } & 6 & & 2 & 1 & & 9 \\
\hline & (66.7) & & $(22.2)$ & (11.1) & & (100) \\
\hline \multirow[t]{2}{*}{ non FHC-normo TC } & 8 & & & & & 8 \\
\hline & $(100)$ & & & & & $(100)$ \\
\hline \multirow[t]{2}{*}{ Total } & 19 & 1 & 2 & 1 & & 23 \\
\hline & $(82.6)$ & (4.3) & (8.7) & (4.3) & & (100) \\
\hline \multirow[t]{2}{*}{ Normal control } & 41 & 3 & 10 & 1 & 1 & 56 \\
\hline & $(73.2)$ & (5.4) & $(17.8)$ & (1.8) & (1.8) & $(100)$ \\
\hline
\end{tabular}

* Number of subjects ** Percentage

とアポ蛋白值を比較検討した成績を示す. 両群の 血清 TC 值の match した症例を選んで比較する と, 前者では, HDL-C 值, apo A-I 值, apo E 值がそれぞれ $56.1 \pm 21.6 \mathrm{mg} / \mathrm{d} l, 137 \pm 30.1 \mathrm{mg} / \mathrm{d} l$, $5.7 \pm 1.3 \mathrm{mg} / \mathrm{d} l$ と後者での $46.1 \pm 13.3 \mathrm{mg} / \mathrm{d} l, 119$ $\pm 21.2 \mathrm{mg} / \mathrm{d} l, 4.1 \pm 1.0 \mathrm{mg} / \mathrm{d} l$ と比較して有意な高 值を呈した。

\section{3. 眼瞼黄色腫患者の血清 apo E phenotype}

Table 3 に今回対象とした眼瞼黄色腫患者の apo E phenotype の出現頻度を正常対照者のも の10) と比較検討した成績を示す. FHC 群では, apo E 3/3 (83\%), apo E 3/2 (17\%), non FHChyper TC 群では apo E 3/3 (66.7\%), apo E 4/3 $(22.2 \%)$, apo E $4 / 4(11.1 \%)$, そして non FHCnormo TC 群では apo E 3/3 (100\%) であった.

したがって眼瞼黄色腫患者全体としてみると， apo E $3 / 3(82.6 \%)$, apo E $3 / 2(4.3 \%)$, apo E $4 / 3$ $(8.7 \%)$, apo E 4/4 (4.3\%) と, 正常対照者と比較 し，著明なかたよりはみられなかった。

\section{4. プロブコール投与中の血清 TC 值の変化}

Figure 5 に，各群の代表的な症例でのプロブコ ール投与時の血清 TC值の変動を示す.ム印, O印, -印はそれぞれ FHC 群, non FHC-hyper TC 群, non FHC-normo TC 群の症例を示す. いずれの 群にてもプロブコール投与 1 か月後より血清 TC 值の低下がみられ，それぞれ約 $20 \%, 15 \%$, $12.5 \%$ の低下がみられた。

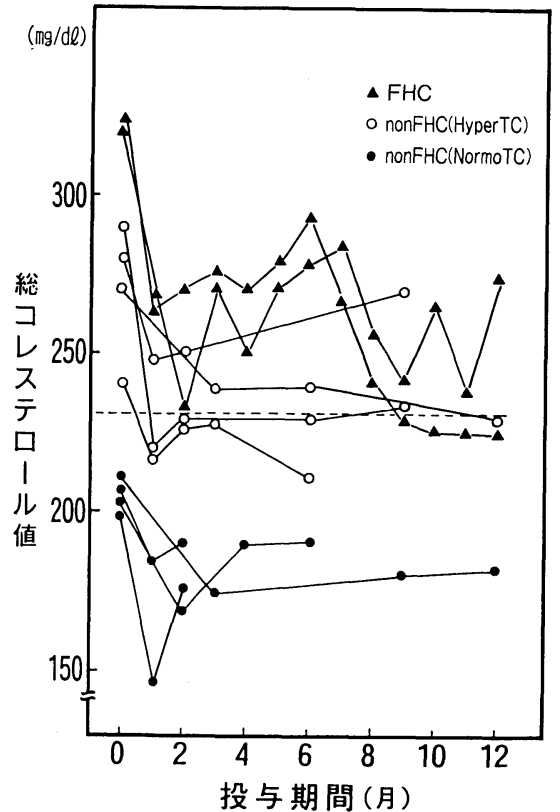

Fig. 5 Effect of probucol treatment on plasma total cholesterol level in xanthelasma patients.

\section{5. プロブコール投与中の眼瞼黄色腫の変化}

Figure 6 に，眼瞼黄色腫を有した一症例にプロ ブコール $500 \mathrm{mg} / \mathrm{d} l$ を 1 年半投与した時のその消 退経過を示す. Fig. 6A はプロブコール投与開始 前, Fig. 6B は投与 1 年後, Fig. $6 \mathrm{C}$ は投与 1 年 半後のものを示す. 軟化し扁平化したものを減少, 黄色調がとれ，周囲皮膚との区別がつかなくなっ 


\section{眼瞼黄色腫患者の臨床像とプロブコールによる治療効果について}

A

B

C

治療後

(1.5年)

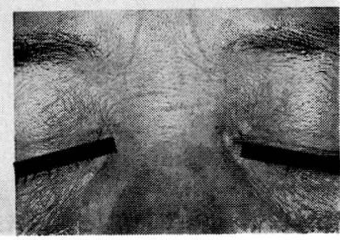

Fig. 6 Effect of probucol treatment on the regression of xanthelasma.
A. before treatment
B. after 1 year
C. after 1.5 years

たものを消失と定義し，前述した 3 群おのおのの 眼瞼黄色腫に対するプロブコール投与の治療成績 を Fig. 7 に示す. いずれの群にても，プロブコー 儿投与開始後 3 か月目より, 眼瞼黄色腫の減少が みられ，1 年後には，半数以上の症例に減少また は消失がみられた。

\section{IV. 考察}

眼瞼黄色腫を有する対象群を FHC 群, non FHC-hyper TC 群 $(\mathrm{TC} \geqq 230 \mathrm{mg} / \mathrm{d} l)$ と non FHCnormo TC 群 $(\mathrm{TC}<230 \mathrm{mg} / \mathrm{d} l)$ の 3 群に分類し, 各群の臨床像とリポ蛋白像を明らかにし，脂質低 下剂プロブコールによるその治療効果を検討した.

FHC 群の 眼瞼黄色腫患者は, 眼瞼黄色腫非保 有患者と比較し，血清 TC, LDL-C, apo B などの いわゆる atherogenic と考えられる因子がより高 值を呈し，反対に antiatherogenic な因子とされ る HDL-C, apo A-I, は低值を示した.さらに, 臨床像にてアキレス腱肥厚がより高度であり, 虚 血性心疾患の発生頻度も有意に高いことから, FHC 群における眼瞼黄色腫の発症は動脈硬化症

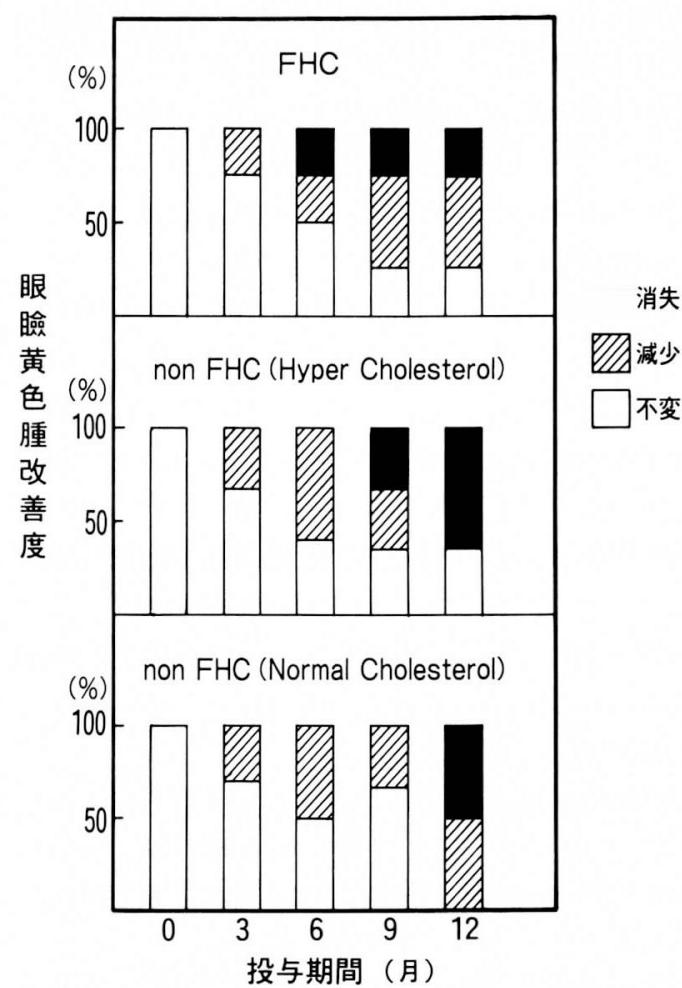

Fig. 7 Effect of probucol treatment on the regression of xanthoma; FHC 6 名, non FHC (hyper cholesterolemia) 8 名, non FHC (normal cholesterolemia) 6 名に対して probucol 500-1,000 $\mathrm{mg} /$ 日を投与した.

の進展と密接に関連しうることが推測された.

Non FHC-hyper TC 群の眼瞼黄色腫患者も, 眼瞼黄色腫非保有患者と比較し, これと類似した 血清脂質, アポ蛋白像を有し, 眼瞼黄色腫と動脈 硬化症の成因として共通の基盤が存在する可能性 が推測された.

次に, normo TC 群の眼瞼黄色腫患者について 同様の検討を行ってみると, 眼瞼黄色腫患者の HDL-C や apo A-I などの antiatherogenic とされ る因子は眼瞼黄色腫非保有患者のものと比較して むしろ高值を呈した。 また, 合併症として, 全身 性エリテマトーデス, シェグレン症候群, 結節性 動脈周囲炎などの全身の血管炎をきたしうる疾患 が存在する症例が散見され, 眼瞼黄色腫の発症に 血清コレステロール以外の因子も関与しうる可能 性が示唆された. 
Apo E phenotype が黄色腫形成に果たす役割を 検討するためその発生頻度を調べると，正常者の ものと比較し，著明なかたよりはみられなかった。 したがって apo E 4/4,3/2 が黄色腫形成に促進因 子として関わることはないものと思われた.

眼瞼黄色腫と動脈硬化症との関連については, Sniderman ら ${ }^{11)} の$ 報告がある. Douste-Blazy'12), 山本 ${ }^{2)}$ らは高脂血症群と正脂血群の眼瞼黄色腫患 者の臨床像を検討し, いずれの群にても眼瞼黄色 腫と動脈硬化症とは密接に関連する可能性を指摘 している. 今回のわれわれの成績からは FHC 群, non FHC-hyper TC 群では眼瞼黄色腫と動脈硬化 症とが密接に関連しうることが示唆された. non FHC-normo TC 群では必ずしもそのような成績 は得られなかったが，今後注意して followする 必要があると思われた。

眼瞼黄色腫に対するプロブコール投与による退 縮効果については, FHC, non FHC-hyper TC, non FHC-normo TC, いずれの群にても減少，な いし消失しうることが示唆された。

そのメカニズムについて，プロブコール投与に よる血清 TC, LDL-C などの atherogenic な因子 の減少，過酸化 LDL 生成の抑制によるマク口フ アージの泡沫化の抑制13) などが指摘されるが, 今後さらに検討を要する.

\section{V. まとめ}

1) FHC 群の眼瞼黄色腫保有患者は, 眼瞼黄 色腫非保有患者と比較し, 血清 TC, LDL-C, apo B が高值を呈し, 血清 HDL-C, apo A-I は低值を 呈し，アキレス腱肥厚がより顕著であり, 虚血性 心疾患の発生頻度が高かった。

2) Non FHC-hyper TC 群の眼瞼黄色腫保有 患者は, 眼瞼黄色腫非保有患者と比較し, 血清 apo B が有意に高く, apo A-I が有意に低かった.

3) Non FHC-normo TC 群の眼瞼黄色腫保有 患者は, 対照群と比較し, 血清 HDL-C, apo A-I, apo E が有意に高かった.

4) 眼瞼黄色腫保有患者の apo E phenotype は, 正常対照群のものと比較し, 著明なかたよりがな かった.

5) FHC, non FHC-hyper TC, non FHC-normo TC，いずれの群にてもプロブコール投与により， 眼瞼黄色腫の改善がみられた。

\section{文献}

1) Rapp, J. H., Connor, W. E., Lin, D. S., Inohara, T. and Porter, J. M.: Lipids of human atherosclerotic plaque and xanthomas: Clues to the mechanism of plaque and progression. J. Lipid Res., 24: 1329_ 1335 (1983).

2) 山本綾子 : 眼瞼黄色腫患者の血漿脂質およびリポ蛋 白検查成績の検討. 日皮会誌,96: 1669-1675 (1986).

3) 和田一成, 三木秀生, 奥田 史雄, 楠川禮造 : ヒト Very Low Density Lipoprotein apo C および apo E peptides の定量と Familial Chylomicronemia な らびに Xanthelasma Palpebraeにみられる特徵. 日 本老年医学会雑誌, 18: 410-416 (1981).

4）多田譲治：プロブコールによる黄色腫治療の試み. 西日皮膚，49: 114-119 (1987).

5）馬㴊 宏, 他：日本人の家族性高コレステロール血 症の診断基準について.日本老年医学雑誌, 14: 475483 (1977).

6) Havel, R. J., Eder, H. A. and Bragdon, J. H.: The distribution and chemical composition of ultracentrifugally separated lipoproteins in human serum. J. Clin. Invest., 34: 1345-1353 (1955).

7) Utermann, G., Pruin, N. and Steinberg, A.: Polymorphism of apolipoprotein $\mathrm{E}$ and occurrence of dysbetalipoproteinemia in man. Nature, 269: 604607 (1977).

8) Mabuchi, H., Ito, S., Haba, T., Ueda, K., Tatami, R., Kametani, T., Koizumi, J., Ohta, M., Miyamoto, S., Takeda, R. and Takegoshi, T.: Discrimination of familial hypercholesterolemia and secondary hypercholesterolemia by Achilles tendon thickness: Atherosclerosis, 28: 61-68 (1977).

9) 白井厚治, 篠宮正樹, 西出敏雄, 斎藤 康, 吉田 尚, 大島仁士, 山下道隆: 冠動脈狭窄度に対するア ポリポ蛋白および脂質との組み合わせ指標の意義. 動脈硬化，14: 1269-1271 (1987).

10) 北原真樹, 篠宮正樹, 白井厚治, 斎藤 康, 吉田 尚：高脂血症に㧍ける apo E phenotype. 動脈硬化, 13: 855-859 (1985).

11) Sniderman, A. D., Wolfson, C., Teng, B., Franklin, F. A., Bacholic, P. S. and Kwiterorich, P. O.: Association of hyperapobetalipoproteinemia with endogenous hypertriglyceridemia and atherosclerosis. Ann. Intern. Med., 97: 833-839 (1982).

12) Douste-Blazy, P., Marcel, Y. L., Cohen, L., Giroux, J. M. and Darignon, J.: Increased frequency of apo E-ND phenotype and hyper apo beta lipoproteinemia in normolipidemic subjects with xanthelasma of the eyelids. Ann. Intern. Med., 96: 164-169 (1982).

13) Carew, T. E., Schwenke, D. C. and Steinberg, D.: Antiatherogenic effect of probucol unrelated to its hypocholesterolemic effect. Proc. Natl. Acad. Sci. U.S.A., 84: 7725-7729 (1987). 


\title{
Summary
}

\section{Clinical Pictures of Patients with Xanthelasma and the Effect of Probucol Treatment}

\author{
Junji Kobayashi*, Kohji Monzawa*, Kohji ShiraI*, Masaki ShinomiYa*, \\ Yasushi SAITo*, Sho YoshidA*, Masaru FuJita**, \\ Hiroshi SUzUKI** and Shoji OKamoto**
}

*The Second Department of Internal Medicine, School of Medicine, Chiba University **The Department of Dermatology, School of Medicine, Chiba University

We investigated the effect of probucol treatment on regression of xanthelasma. The subjects were classified into three groups: a group of familial hypercholesterolemia (FHC), non FHC-hypercholesterolemia (non FHC-hyper TC) (TC $\geqq 230$ $\mathrm{mg} / \mathrm{d} l$ ), and non FHC-normocholesterolemia (non FHC-normo TC) $(\mathrm{TC}<230 \mathrm{mg} / \mathrm{d} l)$, based on the plasma cholesterol levels and the etiology of the disease. In the FHC group, the serum total cholesterol (TC), low density lipoprotein-cholesterol (LDL-C), and apolipoprotein B (apo B) levels were significantly higher; and the serum high density lipoprotein-cholesterol (HDL-C) and apo A-I levels were significantly lower in the subjects with xanthelasma than in those without xanthelasma. In addition, the frequency of ischemic heart disease was higher and the Achilles tendon was thicker in the former than in the latter. In the non FHC-hyper TC group, the serum apo B level was significantly higher and the apo A-I level was lower in the subjects with xanthelasma than in those without xanthelasma. In a group of non FHCnormo TC, the serum HDL-C, apo A-I and apo E levels were significantly higher in subjects with xanthelasma than in those without xanthelasma. In all groups, xanthelasma were tend to regress after 3 months of probucol treatment and the regression or disappearance of xanthelasma was observed in a few cases after 12 months.

Key words: probucol, xanthelasma, atherosclerosis. 